\title{
Introduction species of the genus Eupatorium L. in the southern taiga subzone of Western Siberia
}

\author{
N.V. Kirsanova \\ Siberian botanical garden of the National Research Tomsk State University, 634050 Tomsk, Lenin Ave, 36. \\ Email: tgu.bi@mail.ru
}

The article contains results of six years of observations of introduced populations of Eupatorium cannabinum L., E. maculatum L., E perfoliatum L. and E purpureum L. Seasonal rhythms of development are revealed, some antecological features are investigated, elements of seed productivity are counted and laboratory germination of seeds is estimated. It is established that the studied species are in the full cycle of seasonal development in the southern taiga subzone of Western Siberia: all species are stable vegetate, bloom and bear fruit. Plants are referred to a group of long-term vegetation and summer flowering period cultures. It was found that the flowers of the Eupatorium are characterized by dichogamy in the form of protandry. Species are inherent by high coefficients of seed productivity and fertility of pollen grains. Size indicators of seeds and pollen grains are stable, have a low level of coefficient of variation. Stratification increases the germination of seeds in two times. The studied species can be recommended for use in mixborders, various compositions of landscape style, in the design of garden reservoirs.

Key words: Eupatorium, introduction, antecology, seed production, laboratory germination, seed quality, South of Western Siberia.

\section{Интродукция видов рода Eupatorium L. в подзоне южной тайги Западной Сибири}

\author{
Н.В. Кирсанова \\ Сибирский ботанический сад Начионального исследовательского Томского государственного \\ университета, 634050, г. Томск, пр-т Ленина, 36. Email: tgu.bi@mail.ru
}

В статье приведены итоги шестилетних наблюдений за интродуцированными популяциями четырех видов из рода Eupatorium L. (посконник коноплевидный E. cannabinum L., посконник пятнистый E. maculatum L., посконник пронзеннолистный E. perfoliatum L. и посконник пурпурный E. purpureum L.). Выявлены сезонные ритмы развития, исследованы некоторые антэкологические особенности, подсчитаны элементы семенной продуктивности и оценена лабораторная всхожесть семян. Показано, что в подзоне южной тайги Западной Сибири исследованные виды проходят полный цикл сезонного развития: они стабильно вегетируют, цветут и плодоносят. Растения отнесены к группе длительновегетирующих летнецветущих видов, для цветков установлена дихогамия в форме протандрии. Посконникам свойственны высокие коэффициенты семенной продуктивности и фертильности пыльцевых зерен. Размерные показатели семян и пыльцы стабильны, отличаются низким уровнем коэффициента вариации. Стратификация увеличивает всхожесть семян более чем в два раза. Изученные посконники могут быть рекомендованы для использования в миксбордерах, различных композициях пейзажного стиля, в дизайне садовых водоемов.

Ключевые слова: Eupatorium, интродукция, антэкология, семенная продуктивность, лабораторная всхожесть, качество семян, юг Западной Сибири. 


\section{Введение}

Проблема сохранения биоразнообразия и рационального использования естественных экосистем относится к глобальным проблемам современности. В связи с этим интродукция растений приобретает большое значение, так как способствует сохранению растительных ресурсов, а также обогащению культурной флоры новыми ценными видами и сортами. Культивируемые виды растений, улучшая санитарно-гигиенические и эстетические условия, способствуют оптимизации окружающей среды, создавая благоприятные условия для жизни человека.

Большой интерес с точки зрения практического использования представляют виды из рода Eupatorium L. (Asteraceae). Род насчитывает свыше 600 видов, распространенных в Европе, Азии, тропической Африке и, главным образом, в восточных районах Северной Америки (Plant resources..., 1991; Ito, M. et. al., 2000).

Представители рода - преимущественно многолетние травы и кустарники, реже однолетники с опушением из железистых волосков или голые. Стебли до 2 м высотой, простые, прямые или ветвистые, с супротивными тройчатыми или цельными листьями, реже мутовчатыми цельными листьями. Корзинки соцветия мелкие, колокольчатые, собранные в сложное щитковидное соцветие. Листочки обертки расположены в два-три ряда. Диагностические признаки основаны на строении листочков обертки, корзинок и соцветия в целом. Большинство представителей рода относятся к мезофитам, мезогигрофитам или гигрофитам. Виды произрастают по берегам озер, ручьев, по сырым и болотистым местам (Kirsanova, 2012).

В ландшафтном дизайне посконники получили довольно широкое применение: их высаживают в портерах, миксбордерах, сочетают в посадках с разнообразными декоративными кустарниками. Наиболее крупные виды относят к «архитектурным» растениям, которые могут выступать и в качестве отдельно растущих вертикальных доминантов. Также посконники стали незаменимыми видами при оформлении садовых фонтанов, прудов, ручьев и других водоемов.

Данные виды привлекают внимание и как ценные лекарственные растения. Установлено, что посконники содержат флавоноиды, инулин, смолы, эфирные масла, сесквитерпеновые лактоны, фосфаты железа, кальций, пирролизидиновые алкалоиды и другие биологически активные соединения. Представители рода проявляют седативное, антиоксидантное, гепатопротекторное, антивирусное, антигипоксическое действие. Флавоноиды способствуют желчевыделению и оказывают диуретический эффект. Водный экстракт и масла обладают выраженной антифунгальной активностью (Plant resources..., 1991; Shevchenko \& Sampiev, 2007). В странах Европы и Америки многие виды из представленного рода введены в культуру в качестве декоративных, медоносных и лекарственных растений (Atlas..., 2006). В России интерес к посконникам неуклонно возрастает. Во многих литературных источниках появились достаточно подробные описания как самих видов и сортов посконников, так и особенностей их выращивания (Rubinina, 2005; Atlas ..., 2006; Voronina, 2010; Plants of Crimea..., 2016). Болеe того, отечественные ученые активно исследуют химический состав и фармакологическую активность посконников (Shevchenko \& Sampiev, 2007; Kharina et. al., 2009; Shilina, 2016). На основе травы посконников создаются патенты на изобретения лекарственных средств различного терапевтического действия (Buryakova et. al., 2006; Batukhtin et. al., 2009).

Целью данной работы послужило изучение некоторых биологических особенностей четырех видов из рода Eupatorium L. (E. cannabinum, E. maculatum, E. perfoliatum, E. purpureum) в условиях интродукции в подзоне южной тайги Западной Сибири в связи с перспективами их практического использования.

\section{Материал и методы}

Работы по интродукции посконников в Сибирском ботаническом саду были начаты более 10 лет назад старшим научным сотрудником Т.Г. Хариной. С 2009 г. стали осуществляться более интенсивные экологобиологические исследования представителей данного рода. К настоящему времени интродукционному эксперименту подверглось 15 видов из разных эколого-географических областей. Однако наиболее стабильные адаптивные признаки в условиях юга Западной Сибири были выявлены у четырех видов. Так, регулярное цветение и плодоношение, завязывание качественных семян и наименьшее число вымерзающих особей было отмечено у посконника коноплевидного - Eupatorium cannabinum L., посконника пятнистого - E. maculatum L., посконника пронзеннолистного - E. perfoliatum L. и посконника пурпурного - E. purpureum L. Перечисленные растения распространены преимущественно в районе восточного побережья Северной Америки. На территории России произрастает только посконник коноплевидный. Данный вид встречается в европейской части страны, на Северном Кавказе и Крымском полуострове. Известно, что ареал посконника коноплевидного стремительно сокращается. В Республике Удмуртия, Карелия, Чувашия, а также в Ивановской, Кировской, Костромской, Ленинградской, Новгородской, Оренбургской, Тверской, Ярославской областях вид включен в региональные красные книги (Rare..., 1996).

В данной работе обобщены результаты шести лет (2011-2016 гг.) интродукционных исследований перечисленных посконников. Изначально семена видов были получены из Королевского ботанического сада (Англия), а также из Потсдамского и Берлинского ботанических садов (Германия). Интродукционные исследования проводились уже на особях собственной репродукции, находящихся в средневозрастном онтогенетическом состоянии. Во все годы наблюдений в анализ включалось по 25-30 особей. Растения высаживали через рассаду во 
второй декаде июня в открытый грунт широкорядным способом (междурядья шириной 60 см, между растениями в ряду по 30 см). Уход за растениями заключался в регулярном поливе в первый год жизни, а также в жаркие летние периоды и в 2-3-разовой прополке в течение каждого вегетационного сезона.

Интродукционные исследования проводили с помощью общепринятых методик: ритм сезонного развития I.N. Beydeman (1974); антэкологические исследования A.P. Ponomaryov (1970), A.A. Fyodorov \& Z.T. Artyushenko (1979), V.A. Pukhalskiy et. al. (2007); цитогенетические исследования V.A. Poddubnay-Arnoldi (1982), R.P. Barykina et. al., (2004), V.A. Pukhalskiy et. al. (2007). Изучение семенной продуктивности осуществляли согласно методикам V.I. Vajnagiy (1974), R.E. Levina (1981), N.I. Maysuradze (1984); всхожесть семян R.E. Levina (1981), N.I. Maysuradze (1984), M.G. Nikolaeva et. al. (1985).

При изучении ритма сезонного развития первостепенной задачей является установление сроков прохождения фенофаз растениями за вегетационный период. Нами фиксировались следующие фенологические фазы развития: бутонизация - от появления едва заметных бутонов до начала их развертывания; цветение - от начала развертывания первых цветков через массовое цветение до завязывания плодов, когда остаются открытыми лишь единичные цветки; плодоношение - в условиях интродукционного питомника семена собирались по мере созревания. Фенологические исследования осуществляли 1-2 раза в неделю: со второй декады мая до второй декады сентября.

Также нами изучены фазы развития цветков. Изучение проводилось в летний период на свежих цветках и в зимнее время на материале, фиксированном в растворе Карнуа по методике Z.P. Pausheva (1988). Для определения готовности рылец к восприятию пыльцы пользовались методом Робинсона (Kamelina, 2009). Пестики помещали на 15 мин в 1 \%-ый раствор $\mathrm{KMnO}_{4}$, отмывали в дистиллированной воде и рассматривали интенсивность окрашивания. Рыльца, способные к восприятию пыльцевых зерен, под действием перманганата калия окрашиваются в коричневый цвет, при этом область столбика не окрашивается.

На материале, фиксированном в растворе Карнуа, при окрашивании ацетоорсеином рассматривали морфологию и проводили измерение пыльцевых зерен. При выявлении степени фертильности пыльцевых зерен для каждого вида изготавливалось по 50 временных препаратов в каждый год исследований (2011-2016 гг.). Для этого использовали свежие пыльники, с которых пыльцу стряхивали на предметные стекла. Окраску пыльцевых зерен осуществляли с помощью красителя ацетоорсеина. При этом фертильные пыльцевые зерна окрашиваются в красный цвет, стерильные - в бледно-розовый.

В качестве основных элементов семенной продуктивности были отобраны: число генеративных побегов на особь, число простых парциальных соцветий на один генеративный побег (представлены верхушечным соцветием и соцветиями второго и третьего порядков), число корзинок в парциальном соцветии, число цветков в одной корзинке. В завязи данных представителей развивается одна семяпочка. Вычислялась потенциальная (ПСП) и реальная (РСП) семенная продуктивность, а также коэффициент семенной продуктивности (КСП) - среднее число семян, образовавшихся в плоде, деленное на потенциальную семенную продуктивность.

Проращивание семян проводили в климатических камерах при температуре $\left(+25^{\circ} \mathrm{C}\right)$. В эксперименте использовались семена после 6 месяцев хранения. Семена хранились при комнатной температуре в бумажных пакетах. Семена помещались в чашки Петри на увлажненную фильтровальную бумагу в четырехкратных повторностях по 100 штук. Для нарушения покоя семян использовали холодную стратификацию (0 - -3²). Была также определена всхожесть семян в зависимости от срока хранения.

Статистическую обработку данных проводили с помощью программ «Microsoft Office Excell 2016» и «STATISTICA 12.0». При статистическом анализе вычисляли среднее арифметическое анализируемых параметров, стандартную ошибку $(\mathrm{M} \pm \mathrm{m})$. Для определения уровня изменчивости признаков вычисляли коэффициент вариации (V, \%). При сравнении выборок данных использовали непараметрический критерий Манна-Уитни (Uтест) (при Р<0.05) (Zverev \& Zefirov, 2013).

\section{Результаты и их обсуждение}

Ритм сезонного развития - один из ярких показателей взаимоотношений растительного организма с окружающей средой. От того, насколько пластично растение по данному признаку, как его собственный ритм развития «прилаживается» К климатическому ритму новых условий произрастания, зависит исход акклиматизации (Beydeman, 1974). В связи с этим, момент начала цветения растений, последовательность зацветания видов и продолжительность их цветения очень важны в новых условиях произрастания.

Фаза весеннего отрастания на юге Западной Сибири у изученных видов начинается при сходе снежного покрова и переходе среднесуточных температур через $0-5^{\circ} \mathrm{C}$. В разные годы наблюдений данная фаза наступала в первой - второй декаде мая (табл. 1). Отрастание продолжается до начала формирования репродуктивных органов, является самой длительной фазой и составляет 55-65 дней.

Начало бутонизации, в большинстве случаев, приходится на первую декаду июля, длительность данной фазы составляет 29-38 дней. Начало цветения отмечено в последней декаде июля - первой декаде августа, конец - в первой декаде сентября. Наиболее длительный период цветения характерен для посконника пурпурного - 45 дней, а наименьший период цветения отмечен у посконника пронзеннолистного - 34 дня. Период массового 
цветения составляет 22-30 дней. Начало плодоношения отмечали в середине августа. Длительность плодоношения составила 33-42 дня. Период цветения и плодоношения очень растянут. Прежде всего, это связано со строением соцветия и количеством генеративных побегов на особь. У посконников корзинки 3-7-цветковые, число которых только на главном побеге колеблется от 10 до 20 шт., а число генеративных побегов на особь - 810 шт. (табл. 4). Вследствие сложного строения соцветия на одной особи одновременно присутствуют цветки, находящиеся в разных фенологических фазах развития (бутонизации, цветения и плодоношения). В плодоносящем состоянии растения находятся до начала заморозков.

Таблица 1. Длительность фенологических фаз развития у некоторых видов посконников (Eupatorium L.) в подзоне южной тайги Западной Сибири (2011-2016 гг.)

\begin{tabular}{|c|c|c|c|c|c|c|c|c|}
\hline \multirow{3}{*}{ Вид } & \multicolumn{2}{|c|}{ Вегетация } & \multicolumn{2}{|c|}{ Бутонизация } & \multicolumn{2}{|c|}{ Цветение } & \multicolumn{2}{|c|}{ Плодоношение } \\
\hline & начало & длитель- & начало & длитель- & начало & длитель- & начало & длитель- \\
\hline & конец & ность, дни & конец & ность, дни & конец & ность, дни & конец & ность, дни \\
\hline \multirow[t]{2}{*}{ E. cannabinum } & $\underline{10.05}$ & \multirow{2}{*}{56} & $\underline{01.07}$ & \multirow{2}{*}{34} & $\underline{29.07}$ & \multirow{2}{*}{37} & $\underline{10.08}$ & \multirow{2}{*}{42} \\
\hline & 05.07 & & 03.08 & & 05.09 & & 22.09 & \\
\hline \multirow[t]{2}{*}{ E. maculatum } & 15.05 & \multirow{2}{*}{55} & $\underline{05.07}$ & \multirow{2}{*}{35} & $\underline{03.08}$ & \multirow{2}{*}{35} & 11.08 & \multirow{2}{*}{38} \\
\hline & 09.07 & & 09.08 & & 08.09 & & 08.09 & \\
\hline \multirow[t]{2}{*}{ E. perfoliatum } & $\underline{22.05}$ & \multirow{2}{*}{64} & 19.07 & \multirow{2}{*}{29} & $\underline{03.08}$ & \multirow{2}{*}{34} & $\underline{24.08}$ & \multirow{2}{*}{33} \\
\hline & 25.07 & & 17.08 & & 06.09 & & 26.09 & \\
\hline \multirow[t]{2}{*}{ E. purpureum } & $\underline{08.05}$ & \multirow{2}{*}{65} & $\underline{02.07}$ & \multirow{2}{*}{38} & $\underline{01.08}$ & \multirow{2}{*}{45} & $\underline{15.08}$ & \multirow{2}{*}{38} \\
\hline & 12.07 & & 09.08 & & 15.09 & & 22.09 & \\
\hline
\end{tabular}

Примечание: над чертой представлена дата начала (число.месяц) фенологической фазы развития, под чертой дата завершения.

Таким образом, по существующей классификации (Serebryakov, 1964; Golubev, 1965), изученные посконники относятся к длительновегетирующим летнезеленым растениям с зимним типом покоя, а по типу цветения - к среднепозднелетним. По мнению I.N. Beydeman (1974), особенности сезонного ритма растения определяются историко-ботанико-географическими причинами, т.е. растение, жившее ранее при других условиях среды, сохраняет ритм сезонного развития при изменении внешних условий (климата, почвы и т.д.). Полученные нами данные по сезонному развитию представленных видов согласуются с этой точкой зрения. Длительная вегетация и растянутый характер прохождения фенологических фаз соответствуют более мягкому климату мест, где данные виды исторически произрастают (восточное побережье Северной Америки, Средиземноморье, Европа, Кавказ, Крым).

Опыление - один из этапов семенного размножения, включающий перенос пыльцы в период цветения растений. Чтобы произошло опыление, необходимо наличие целого ряда составляющих этого процесса: цветение, наличие в цветках жизнеспособной пыльцы, активность переносчиков пыльцы и готовность рыльца к её восприятию.

Растения рода Eupatorium имеют сложные составные (агрегатные) соцветия. У изученных видов соцветия представлены щитком корзинок. Ветвление главной оси соцветия и характер расположения боковых осей осуществляется по щитковидному типу, тогда как на конечных осях парциальных соцветий развиваются корзинки. Корзинки 8-13 мм дл. Обертки 2-3-рядные, черепитчатые, колокольчатые, несколько короче цветков из 9-10 листочков. Наружные листочки яйцевидные опушенные, внутренние - ланцетные голые, по краю перепончатые. Корзинки состоят из 3-7 цветков. Венчики цветков грязно-розовые или белые. Цветки воронковидные, с пятью мелкими и острыми зубчиками. Лопасти рыльца 2-4 мм дл., выставляющиеся из венчика, нитевидные, полуцилиндрические, тупые, коротко опушенные. Пыльники вытянутой формы при основании закругленные, 0,8-1,2 мм дл.в числе пяти штук, каждый из которых состоят из 4-х микроспорангиев. Пыльники срастаются в трубку вокруг столбика пестика, тычиночные нити - свободные. Цветки открываются однократно в течение дня и закрываются на ночь. Распускаться цветки начинают рано утром (в 7-8 часов), закрываются вечером (в 20-21 часов). В ясные и солнечные дни массовое распускание цветков наблюдается в 12-15 часов, когда температура воздуха достигает $20-25^{\circ} \mathrm{C}$. В пасмурные и дождливые дни было отмечено значительное сокращение числа распустившихся цветков.

Эффективность опыления во многом связана со способом переноса пыльцы с цветка на цветок. У изученных видов единицей опыления, является соцветие, поскольку оно более аттрактивно для опылителей, нежели отдельные цветки. Характерные для посконников, верхушечные, многоцветковые, грязно-розовые соцветия рассматриваются как одна из форм адаптации к энтомофильному типу опыления. Соцветие такого типа является своего рода «плацдармом с обилием пыльцы» для насекомых опылителей (Fegri \& Peyl, 1982). Для данных видов, как и для большинства представителей Asteraceae, характерна энтомофилия с преобладанием частного случая мелиттофилия (опыление пчелами Apis sp., шмелями Bombus sp., осами Vespula sp.). Нами также отмечено редкое посещение цветков дневными бабочками Lepidoptera Linnaeus. Активность насекомых опылителей в течение суток зависит от метеорологических условий: в солнечные дни посещение цветков насекомыми начинается с 
момента распускания цветков, когда температура воздуха достигает 16-18 С и продолжается до 20-21 часа. Максимальное число опылителей отмечено в период с 12 до 15 часов, т.е. во время массового распускания цветков.

В литературе отсутствуют детальные описания фаз развития цветков у представителей данного рода, за исключением классической сводки P. Knuth (1905), где указывается на то, что для посконников характерна ксеногамия, а перенос пыльцы осуществляется насекомыми.

Проведенные нами некоторые эмбриологические исследования показали, что гаметогенез у посконников отмечен в бутонах размером от 1.7 до 2.0 мм, где появляются свободные (одиночные) микроспоры. Рассчитан мейотический индекс, т.е. процент нормальных тетрад, составивший 95-100 \% в зависимости от вида, что свидетельствует о цитологической стабильности изученного материала. Исследование фаз развития цветка проводилось в бутонах, когда они достигли размера 2 мм дл., где появляется зрелая пыльца, а также на цветках с установлением качественно различных фаз по признакам времени роста и раскрывания частей цветка, созревания рыльца для восприятия и прорастания пыльцы. У данных представителей выделено две фазы развития цветка: тычиночная и пестичная.

Тычиночная фаза протекает в бутоне и характеризуется ростом тычиночной нити соответственно увеличению размера бутона. На стадии рыхлого бутона пыльники вскрываются продольной трещиной, и начинается пыление.

В пестичной фазе у посконников выявлено две стадии развития гинецея: рост завязи и увеличение столбика в бутоне, и рост столбика и рылец в открытом цветке (табл. 2). Причем рост пестика в стадии бутона идет в три этапа, а на стадии цветка - в два.

Таблица 2. Этапы пестичной фазы развития цветка у некоторых видов посконников (Eupatorium L.) в подзоне южной тайги Западной Сибири

\begin{tabular}{|c|c|c|c|c|c|c|c|c|c|c|}
\hline & \multirow[b]{2}{*}{$\begin{array}{l}\overline{0} \\
\stackrel{2}{5} \\
\stackrel{0}{n} \\
\end{array}$} & \multirow[b]{2}{*}{$\begin{array}{l}\text { краткая } \\
\text { характерис } \\
\text { тика }\end{array}$} & \multicolumn{2}{|c|}{ Eupatorium cannabinum } & \multicolumn{2}{|c|}{ Eupatorium maculatum } & \multicolumn{2}{|c|}{ Eupatorium perfoliatum } & \multicolumn{2}{|c|}{ Eupatorium purpureum } \\
\hline & & & $\begin{array}{l}\text { длина } \\
\text { бутона, } \\
\text { мм } \\
\end{array}$ & $\begin{array}{l}\text { степень } \\
\text { окрашивания } \\
\text { пестика }\end{array}$ & $\begin{array}{l}\text { длина } \\
\text { бутона, } \\
\text { мм } \\
\end{array}$ & $\begin{array}{l}\text { степень } \\
\text { окрашивания } \\
\text { пестика } \\
\end{array}$ & $\begin{array}{l}\text { длина } \\
\text { бутона, } \\
\text { мм } \\
\end{array}$ & $\begin{array}{l}\text { степень } \\
\text { окрашивания } \\
\text { пестика }\end{array}$ & $\begin{array}{l}\text { длина } \\
\text { бутона, } \\
\text { мм } \\
\end{array}$ & $\begin{array}{l}\text { степень } \\
\text { окрашивания } \\
\text { пестика }\end{array}$ \\
\hline & I & $\begin{array}{l}\text { стадия } \\
\text { плотного } \\
\text { бутона, рост } \\
\text { столбика, } \\
\text { лопасти } \\
\text { рыльца } \\
\text { сомкнуты }\end{array}$ & $2.0-2.4$ & - & $2.0-2.5$ & + & $2.0-2.5$ & - & $2.0-2.6$ & + \\
\hline & II & $\begin{array}{l}\text { увеличение } \\
\text { бутона в } \\
\text { длину, рост } \\
\text { лопастей } \\
\text { рыльца }\end{array}$ & $2.4-2.8$ & + & $2.5-3.0$ & + & $2.5-2.8$ & + & $2.6-3.0$ & + \\
\hline$\frac{1}{0}$ & III & $\begin{array}{l}\text { стадия } \\
\text { рыхлого } \\
\text { бутона, } \\
\text { расхождение } \\
\text { лепестков } \\
\text { венчика, } \\
\text { начало } \\
\text { изгибания } \\
\text { лопастей } \\
\text { рыльца }\end{array}$ & $2.8-3.0$ & ++ & $3.0-3.5$ & ++ & $2.8-3.2$ & ++ & $3.0-3.4$ & ++ \\
\hline 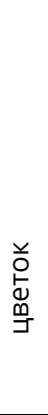 & I & $\begin{array}{l}\text { стадия } \\
\text { зрелого } \\
\text { цветка, } \\
\text { усиленный } \\
\text { рост столбика } \\
\text { и лопастей } \\
\text { рыльца, } \\
\text { полное } \\
\text { изгибание } \\
\text { лопастей } \\
\text { рыльца }\end{array}$ & $3.0-4.0$ & - & $3.5-4.5$ & + & $3.2-4.0$ & - & $3.4-4.5$ & - \\
\hline
\end{tabular}


стадия

увядания

II цветка,

закручивание 4.0-6.5 - $4.5-7.0 \quad-\quad 4.0-6.2$ - $4.5-8.0 \quad$ -

лопастей

рыльца

Примечание. + точечное окрашивание лопастей рыльца, ++ полное окрашивание лопастей рыльца, прочерк - лопасти рылец не окрашены.

Первый этап стадии роста пестика характеризуется плотно сомкнутыми лопастями рыльца. На втором этапе с ростом бутона наблюдается рост столбика, при этом лопасти рыльца начинают расходиться. На третьем этапе стадии рыхлого бутона - лопасти рыльца широко расставлены, на них появляется множество мелких сосочков.

На стадии цветка у данных видов происходит полное раскрытие лопастей рылец с их последующим закручиванием и увяданием венчика цветка.

Большой интерес для понимания биологии цветения и опыления представляет изучение восприимчивости рылец к пыльце на разных стадиях развития гинецея. Полное окрашивание рыльца пестика перманганатом калия в реакции Робинсона свидетельствует о его готовности к восприятию пыльцы. Нами установлено, что для посконников точечное окрашивание начинающих раскрываться лопастей рыльца происходит уже на первом этапе роста пестика в бутоне, но лишь с появлением сосочков на рыльце наступает полное окрашивание. Для видов характерно закручивание лопастей рыльца на стадии раскрытого цветка при отсутствии их окрашивания, что свидетельствует об окончании функционирования пестика, который уже не способен воспринимать пыльцу (табл. 2).

Анализ сроков созревания андроцея и готовности рыльца к восприятию пыльцы показал разновременное созревание половых продуктов. Сначала завершается мужская фаза развития - происходит формирование зрелого мужского гаметофита и начинается пыление, позже обнаруживается готовность рыльца пестика к восприятию пыльцы. Таким образом, для данных видов установлена дихогамия в форме протандрии, которая, как отмечает V.A. Poddubnay-Arnoldi (1982) является приспособлением к перекрестному опылению (ксеногамии).

При изучении биологии цветения и опыления растений важным вопросом является выявление фертильности пыльцевых зерен, поскольку именно пыльца играет большую роль в формировании наследственных признаков семян (Poddubnay-Arnoldi, 1982).

Зрелые пыльцевые зерна исследованных видов одиночные, шаровидные, радиально-симметричные, трехапертурные. Апертуры представляют собой борозды меридионального простирания. Борозды длинные, сужающиеся к концам. Скульптура экзины характеризуется наличием шипиков. Различия пыльцевых зерен изученных видов заключается, главным образом, в размерных показателях. Пыльца с наименьшим диаметром отмечена у посконника коноплевидного - 9.28 мкм, наиболее крупные пыльцевые зерна характерны для посконника пурпурного - 11.5 мкм (табл. 3). Строение, величина и форма пыльцы данных видов полностью отвечает характерным особенностям пыльцы энтомофильных растений.

Средние показатели фертильности пыльцевых зерен немного снижены, не превышат 78 \%. Снижение процента фертильности пыльцы может быть обусловлено нарушением течения мейоза при микроспорогаметогенезе, погодными условиями, а также загрязнением атмосферы.

Таблица 3. Морфометрические показатели пыльцевых зерен и семян у некоторых видов посконников (Eupatorium L.) в подзоне южной тайги Западной Сибири (2011-2016 гг.)

\begin{tabular}{|c|c|c|c|c|c|c|}
\hline Вид & $\begin{array}{l}\text { Диаметр } \\
\text { пыльцевых } \\
\text { зерен, мкм }\end{array}$ & $\begin{array}{l}\text { Фертильность } \\
\text { пыльцевых зерен, } \\
\%\end{array}$ & $\begin{array}{l}\text { Длина семян, } \\
\text { мм }\end{array}$ & $\begin{array}{l}\text { Ширина } \\
\text { мм }\end{array}$ & семян, & $\begin{array}{l}\text { Масса } 1000 \text { шт. } \\
\text { семян, гр. }\end{array}$ \\
\hline E. cannabinum & $9.28 \pm 0.05$ & $77.9 \pm 3.8$ & $2.8 \pm 0.02$ & $1.8 \pm 0.01$ & & $0.3 \pm 0.01$ \\
\hline E. maculatum & $10.18 \pm 0.09$ & $68.9 \pm 7.5$ & $2.4 \pm 0.02$ & $1.5 \pm 0.01$ & & $0.4 \pm 0.01$ \\
\hline E. perfoliatum & $9.88 \pm 0.09$ & $70.6 \pm 5.5$ & $2.6 \pm 0.01$ & $1.6 \pm 0.01$ & & $0.6 \pm 0.01$ \\
\hline E. purpureum & $11.50 \pm 0.03$ & $69.3 \pm 5.6$ & $3.2 \pm 0.04$ & $2.0 \pm 0.01$ & & $0.8 \pm 0.01$ \\
\hline
\end{tabular}

Плоды посконников - семянки (далее везде семена) с пятью ребрами, продолговатые, темно-бурые, голые или короткожелезистые, на верхушке усеченные, книзу суженные. На верхушке имеется белый, однорядный хохолок из длинных шероховато зазубренных не опадающих свободных волосков. Формирование жизнеспособных семян зависит от внутренних и внешних факторов, влияющих на стадии формирования и развития зародыша. Количество семяпочек на особь или генеративный побег отражает потенциальную семенную продуктивность (ПСП), а фактическое число образовавшихся семян является реальной семенной продуктивностью (РСП). Как правило, число жизнеспособных, полноценных семян формируется меньше, чем 
закладывается семязачатков. Таким образом, имеет смысл применение коэффициента семенной продуктивности (КСП) (Vajnagiy, 1974) для изучения изменчивости ПСП и РСП.

Как видно из таблицы 4, за счет формирования большого числа генеративных побегов и сложного многоцветкового соцветия для посконников характерны довольно высокие показатели элементов семенной продуктивности. Так, у посконика коноплевидного РСП составляет в среднем 68745 семян на особь, у посконника пронзеннолистного - 58146 семян, у посконников пятнистого и пурпурного данный показатель снижен до 30-36 тыс. семян на особь соответственно. Коэффициенты семенной продуктивности также довольно высокие - до 92.6 \%. КСП немного снижен лишь у посконника пятнистого (76.0%). Высокие показатели РСП и КСП, а также низкие и средние значения коэффициентов вариации элементов семенной продуктивности отражают благополучие и надежность, как популяции, так и вида в целом в новых условиях произрастания (Dorogina, 2007).

Таблица 4. Показатели семенной продуктивности у некоторых видов посконников (Eupatorium L.) в подзоне южной тайги Западной Сибири (2011-2016 гг.)

\begin{tabular}{|c|c|c|c|c|c|}
\hline & Число & Число цветков & & & \\
\hline Вид & $\begin{array}{l}\text { генеративных } \\
\text { побегов на } \\
\text { особь, шт. }\end{array}$ & $\begin{array}{l}\text { на } \\
\text { генеративный } \\
\text { побег, шт. }\end{array}$ & $\begin{array}{l}\text { ПСП на особь, } \\
\text { шт. }\end{array}$ & $\begin{array}{l}\text { РСП на особь, } \\
\text { шт. }\end{array}$ & КСП на особь, \% \\
\hline \multirow[t]{2}{*}{ E. cannabinum } & $\underline{10.8 \pm 1.2}$ & $\underline{7011.8 \pm 843.0}$ & $\underline{74473.7 \pm 8181.0}$ & $\underline{68745.0 \pm 6594.6}$ & $\underline{92.6 \pm 5.32}$ \\
\hline & 11.1 & 12.0 & 10.9 & 9.5 & 5.75 \\
\hline \multirow[t]{2}{*}{ E. maculatum } & $\underline{8.3 \pm 1.4}$ & $\underline{4990.6 \pm 565.3}$ & $40322.6 \pm 5763.0$ & $\underline{30566.6 \pm 4678.0}$ & $76.0 \pm 8.4$ \\
\hline & 16.1 & 11.3 & 14.3 & 15.3 & 11.0 \\
\hline \multirow[t]{2}{*}{ E. perfoliatum } & $10.0 \pm 1.5$ & $\underline{6875.7 \pm 876.4}$ & $\underline{68513.9 \pm 8965.0}$ & $\underline{58146.0 \pm 5322.0}$ & $\underline{84.8 \pm 9.1}$ \\
\hline & 15.0 & 12.7 & 13.0 & 9.1 & 10.7 \\
\hline \multirow[t]{2}{*}{ E. purpureum } & $\underline{8.0 \pm 1.3}$ & $\underline{5122.5 \pm 770.0}$ & $\underline{39284.6 \pm 5554.0}$ & $\underline{36043.0 \pm 5295.0}$ & $91.0 \pm 2.3$ \\
\hline & 16.3 & 15.0 & 14.1 & 14.6 & 6.6 \\
\hline
\end{tabular}

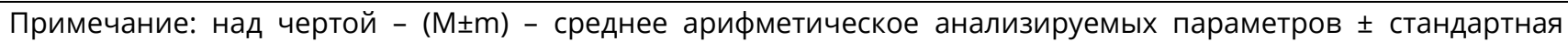
ошибка, под чертой - V, \% - коэффициент вариации; ПСП - потенциальная семенная продуктивность, РСП реальная семенная продуктивность, КСП - коэффициент семенной продуктивности

Семенная продуктивность - количественная характеристика семян, в то время как качественная характеристика определяется их размерами, массой 1000 шт. и всхожестью. Семена посконников без эндосперма, зародыш занимает всю полость семени. Зародыш слабо дифференцирован, содержит две семядоли и зародышевый корешок. При сравнении морфологических показателей семян посконников значимых различий выявлено не было. Так, длина семян составляет 2.8-3.2 мм, ширина 1.5-2.0 мм, масса 1000 шт. - 0.3-0.8 г (табл. 3). Выявлено, что для семян данных видов характерна также схожая динамика прорастания (табл. 5). Семена имеют два пика всхожести: на 6-8 день опыта и на 20-26 день. Для семян характерен длительный период прорастания 30-32 дня. Максимальное число проросших семян отмечается на 20-26 день и соответствует 3-6 шт. Наибольшая общая всхожесть отмечена у посконника коноплевидного - 16 \%. Длительная холодовая стратификация повышает всхожесть, более чем в два раза. Так, после двадцатидневной стратификации всхожесть увеличилась до 45-47 \% в зависимости от вида.

Таблица 5. Лабораторная всхожесть семян некоторых видов посконников (Eupatorium L.) в подзоне южной тайги Западной Сибири (средние данные 4-кратной повторности за 2011-2016 гг.)

\begin{tabular}{|c|c|c|c|c|c|c|c|c|c|c|c|c|}
\hline \multirow{2}{*}{$\begin{array}{l}\text { Срок хранения } \\
\text { семян }\end{array}$} & \multicolumn{3}{|c|}{ Eupatoriumcannabinum } & \multicolumn{3}{|c|}{ Eupatoriummaculatum } & \multicolumn{3}{|c|}{$\begin{array}{l}\text { Eupatorium } \\
\text { perfoliatum }\end{array}$} & \multicolumn{3}{|c|}{ Eupatoriumpurpureum } \\
\hline & $\begin{array}{l}\mathrm{N}_{(6-8)} \\
\text { шт. }\end{array}$ & $\begin{array}{l}\mathrm{N}_{(20-} \\
\text { 26)! } \\
\text { ШT. }\end{array}$ & $N_{n}, \%$ & $\begin{array}{l}\mathrm{N}_{(6-8)} \\
\text { шт. }\end{array}$ & $\begin{array}{l}\mathrm{N}_{(20-} \\
\text { 26) } \\
\text { ШT. }\end{array}$ & $N_{n}, \%$ & $\begin{array}{l}\mathrm{N}_{(6-8) !} \\
\text { шт. }\end{array}$ & $\begin{array}{l}\mathrm{N}_{(20-26)} \\
\text { шт. }\end{array}$ & $\begin{array}{l}\mathrm{N}_{\mathrm{n}} \\
\%\end{array}$ & $\begin{array}{l}\mathrm{N}_{(6-8),} \\
\text { шт. }\end{array}$ & $\begin{array}{l}\mathrm{N}_{(20-} \\
\text { 26)ı } \\
\text { ШT. }\end{array}$ & $\mathrm{N}_{\mathrm{n}}, \%$ \\
\hline свежесобранные & $2-4$ & $4-8$ & $9-11$ & $1-3$ & $5-7$ & $8-11$ & $1-2$ & $3-6$ & $4-9$ & $2-4$ & $2-6$ & $10-13$ \\
\hline 2-3 мес. & $4-8$ & $8-10$ & $22-30$ & $3-6$ & $7-11$ & $16-18$ & $2-6$ & $6-9$ & $8-18$ & $4-6$ & $4-9$ & $25-28$ \\
\hline 5-6 мес. & $2-4$ & $3-6$ & $11-16$ & $1-2$ & $4-6$ & $8-10$ & $2-4$ & $4-6$ & $6-10$ & $2-3$ & $2-5$ & $9-14$ \\
\hline 1 год & $1-2$ & 1 & $5-7$ & - & $2-3$ & $4-7$ & 1 & $1-2$ & $3-5$ & $1-2$ & - & $3-4$ \\
\hline 2 года & - & 1 & 1 & - & - & - & - & - & - & - & - & - \\
\hline
\end{tabular}

Примечание: $\mathrm{N}_{(6-8)}$ - минимальное и максимальное число проросших семян на 6-8 день опыта, шт.; $\mathrm{N}_{(20-26)}$ минимальное и максимальное число проросших семян на 20-26 день опыта, шт.; Nn общая всхожесть, \%. 
Изучение прорастания семян посконников в зависимости от срока хранения показало, что свежесобранные семена имеют пониженную всхожесть - 4-13 \%. Спустя 2-3 месяца хранения наблюдается увеличение числа проросших семян в несколько раз (до 30 \%). После 5-6 месяцев хранения всхожесть снижается до уровня свежесобранных семян. Как утверждает M.G. Nikolaeva с соавторами (1985), подобные особенности всхожести семян указывают на их неглубокий физиологический покой. Согласно литературным данным семена большинства представителей семейства астровых характеризуются неглубоким физиологическим покоем (Nikolaeva, 1985). Хранение в течение года показало дальнейшее снижение числа проросших семян до 3-7 \%. После двух лет хранения наблюдается единичное прорастание семян, характерное только для посконника коноплевидного. После трех - четырех лет хранения прорастание семян не наблюдается.

\section{Выводы}

Виды из рода Eupatorium L. являются ценными лекарственными, декоративными и медоносными растениями. В связи с чем введение их в культуру представляет большой научный и практический интерес. В условиях интродукции в подзоне южной тайги Западной Сибири наиболее устойчивые адаптивные признаки к неблагоприятным факторам среды были выявлены у посконника коноплевидного - Eupatorium cannabinum L., посконника пятнистого -E. maculatum L., посконника пронзеннолистного - E. perfoliatum L. и посконника пурпурного - E. purpureum L. Представленные виды отнесены к группе длительновегетирующих летнезеленых растений с зимним типом покоя. По типу цветения изученные посконники являются средне-позднелетними, по типу суточного ритма распускания цветков принадлежат к группе дневных растений. На основе изучения фаз развития цветка, степени готовности рылец к восприятию пыльцы, особенностей их морфологии и фертильности у изученных представителей выявлены дихогамия в форме протандрии и ксеногамный тип опыления. Пыльцевые зерна мелкие, шаровидной формы, трехбороздные, экзина характеризуется наличием шипиков. Фертильность пыльцевых зерен не превышает 78 \%. Исследованным видам свойственен высокий коэффициент семенной продуктивности (до 92.6 \%). Семена мелкие: длина - 2.8-3.2 мм, ширина 1.5-2.0 мм. Лабораторная всхожесть не превышает 16 \%. Стратификация увеличивает всхожесть семян более чем в два раза. В целом все изученные виды посконников проходят полный цикл сезонного развития: они стабильно вегетируют, цветут и плодоносят, имеют высокий процент семенной продуктивности, нормальный ритм распускания цветка, что свидетельствует о пластичности и приспособлении кновым условиям произрастания.

\section{Благодарность}

Автор выражает благодарность за помощь в проведении исследований старшему научному сотруднику сибирского ботанического сада Т.Г. Хариной.

\section{References}

Atlas of medicinal plants of Russia (2006). V.A. Bykov (Ed.). Moscow: All-Russian Institute of medicinal and aromatic plants (in Russian).

Barykina, R.P., Veselova, D.T., Devyatov, A.P. (2004). Handbook of Botanical micro-technology. Moscow: Publishing House Moscow State University (in Russian).

Beydeman, I.N. (1974). The method of study of phenology of plants and plant communities. Novosibirsk: Nauka. Siberian department (in Russian).

Dorogina, O.B. (2007). The importance of reproductive systems in the study of biodiversity and plant adaptation. Siberian Botanical Bulletin, 2(1), 91-94 (in Russian).

Fegri, K. \& L. van der Peyl (1982). Fundamentals of pollination ecology. Leningrad: Nauka (in Russian).

Fyodorov, A.A. \& Artyushenko, Z.T. (1979). Atlas of descriptive morphology of embryophyta. Inflorescence. Leningrad: Nauka (in Russian).

Golubev, V.N. (1965). Ecological and biological features of herbaceous plants and plant communities of the forest-steppe. Moscow: Nauka (in Russian).

Ito, M., Watanabe, K., Kita, Yo., Kawahara, T., Crawford, DJ, Yahara, T. (2000). Phylogeny and Phytogeography of Eupatorium (Eupatorieae, Asteraceae): Insights from Sequence Data of the nrDNA ITS Regions and cpDNA RFLP. Journal of Plant Research, 113(1), 79-89.

Kamelina, O.N. (2009). Systematic embryology of flowering plants. Barnaul: Publishing House "ARTIKA" (in Russian).

Kharina, T.G., Babicheva, N.V., Leshchuk, R.I. (2009). Morphological and biochemical characteristics of Eupatorium cannabinum L. when introduced in the vicinity of Tomsk. Botanical research in the Urals. Perm branch of the Russian Botanical society (in Russian).

Kirsanova, N.V. (2012). Ecological and biological characteristics of Eupatorium cannabinum L. in connection with introduction in the southern taiga subzone of Western Siberia. Thes is of Doctoral Dissertation. Tomsk (in Russian).

Knuth, P. (1905) Guide to flowering biology. Leipzig (in German).

Levina, R.E. (1981). Reproductive biology of seed plants. Moscow: Nauka (in Russian). 
Maysuradze, N.I. (1984). Medicinal plant growing.Methods of research in the introduction of medicinal plants. Moscow: Medicine (in Russian).

Nikolaeva, M.G., Razumova, M.V., Gladkova, B.N. (1985). Handbook to germination of dormant seeds. Leningrad: Nauka (in Russian).

Patent of Russia on a homeopathic remedy "anapirin-homeopathie" with an antiviral effect (options). Buryakova, I.V., Kurilova, A.I., Badytchik, L.I., Zamarenov, N.A. № 2311194, 24.08.2006 (in Russian).

Patent of Russia on the means having antihypoxic effect. Batukhtin, V.A., Shilov, I.V., Suslov, N.I. Kharina, T.G., Babicheva, N.V. № 2392956, 02.03.2009 (in Russian).

Pausheva, Z.P. (1988). Workshop on plant cytology. Moscow: Agropromizdat (in Russian).

Plant resources of the USSR. Flowering plants, their chemical composition and use. Family of Asteraceae (1991). P.D. Sokolov (Ed.). Saint-Petersburg: Nauka, VII.,114-115 (in Russian).

Plants of Crimea: delightful neighbors (2016). Y.V. Plugatar (Ed.). Simferopol: Publishing House "ARIAL". (in Russian).

Poddubnay-Arnoldi, V.A. (1982). Characteristics of the angiosperms families by cytoembryological characteristics. Moscow: Nauka (in Russian).

Ponomaryov, A.P. (1970). About methods and directions anthecological research. Scientific notes of the Perm University. Ser. Biology, 206, 3-10 (in Russian).

Pukhalskiy, V.A., Solovyov, A.A., Badaeva, E.D., Yurtsev, V.N. (2007). Practicum on plant cytology and cytogenetics. Moscow: Kolos (in Russian).

Rare and endangered species of plants, fungi and lichens of the Rostov region (1996). V.V. Fedyaeva (Ed.). Rostov-on-

Don: Publishing House "Paik" (in Russian).

Rubinina, A.V. (2005). Eupatorium like designers. News of the florist, 8, 16-18 (in Russian).

Serebryakov, I.G. (1964). Comparative analysis of some features of the rhythm of seasonal development of various botanical-geographical zones of the USSR. Bulletin of the Moscow society of naturalist, 49(5), 62-75 (in Russian).

Shevchenko, A.I. \& Sampiev, A.M. (2007). Aminoacid and mineral composition of the herb Eupatorium cannabinum. News of tertiary education institutions. North Caucasus region. Series: Natural sciences, 4, 92-93 (in Russian).

Shilina, T.S. (2016). Obtaining medicines on the basis of the herb Eupatorium cannabinum. Actual problems of medicine in Russia and abroad (in Russian).

Vajnagiy, V.I. (1974). On the method of studying the seed productivity of plants. Botanical journal, 59(6), 826-831 (in Russian).

Voronina, S.I. (2010). Perennial flowers in garden design. Moscow: Fiton Plus (in Russian).

Zverev, A.A. \& Zefirov, T.L. (2013). Statistical methods in biology: educational and methodical manual. Kazan: Kazan Federal University Press (in Russian).

\section{Citation:}

Kirsanova, N.V. (2018). Introduction species of the genus Eupatorium L. in the southern taiga subzone of Western Siberia. Acta Biologica Sibirica, 4 (3), 121-129.

Submitted: 1 08.2018.Accepted: 01.09.2018

crossref http://dx.doi.org/10.14258/abs.v4i3.4417

(C) 2018by the authors.Submitted for possible open access publication under the terms and conditions of the Creative Commons Attribution (CC BY) license (http://creativecommons.org/licenses/by/4.0/). 